\title{
PATTERN OF ISLAMIC MORAL DEVELOPMENT FOR CHILDREN WITH SPECIAL NEEDS (BLIND)
}

\author{
${ }^{1}$ Umar Sidiq \& ${ }^{2}$ Nurul Aini \\ 1,2 IAIN Ponorogo \\ ${ }^{1}$ umarsidiqstainponorogo@gmail.com \\ ${ }^{2}$ nurulainistainponorogo@gmail.com
}

\begin{abstract}
Blind is a person who has a disorder in his vision. A person's blindness is caused by endogenous factors such as hereditary, or due to exogenous factors, such as accidents, drugs and others. The main obstacle of a blind child is not working in his sense of vision. So that children with visual impairments, including children with special needs, are children who experience physical disorders that are different from normal children so that children with visual impairments need special education services and guidance so they can develop their potential as optimally as possible. This study aims to describe the foundation of guidance carried out on children with special needs (blind), as well as to describe aspects of coaching for children with special needs (blind). This study included qualitative research with a descriptive approach. Aisyiah Ponorogo Orphanage as a nonformal educational institution that carries out its duties and functions in learning and fostering children, including dealing specifically with children who have visual impairments. In such a long period of time, there are certainly many records and experiences in the development of blind children.
\end{abstract}

Keywords: Pattern of Development, Islamic Moral, Children with Special Needs, Blindness.

\section{INTRODUCTION}

Education is the right of every child, without exception. As in the 1945 Constitution Chapter XIII article 31 paragraph (1) it is stated that "Every citizen has the right to receive teaching, and in paragraph (2) it is stated that the government undertakes and organizes a national teaching system regulated by law". (UUD 1945) Based on the 1945 Constitution, in essence there is no difference between those who are normal and those who have abnormalities, all citizens have the right to obtain teaching. Therefore the government provides special education to those who have special needs. 
As stipulated in Law No. 20/2003 article 5 paragraph 2 that: "Citizens who have physical, emotional, mental, intellectual, and/or social abnormalities have the right to receive special education" (UUD 1945).

So it is clear that education in our country knows no discrimination, all levels of society from any group will get the same rights in terms of education is no exception for children who have physical or mental disorders that can hinder their learning.

Coaching from families to children, especially children with special needs (blind) is sometimes not as expected because of lack of knowledge so that they parents need help from special education institutions to help provide guidance to their children.

Education is not only obtained from the school environment, but also from outside the school both in the family environment and through other non-formal education institutions. Especially for children who have special needs, they certainly need a lot of guidance that is not only obtained from the school. One of them is at the Aisyah Ponorogo Orphanage, where children get special guidance from orphanage caregivers including blind children. Besides getting their coaching also get additional learning like in formal school.

\section{DISCUSSION}

\section{Principles in Submitting Materials to Children with Special Needs}

In the delivery of material, especially for children with special needs, there is no harm if an educator must also consider several principles, including the following (Effendi, 2006).

a. Principle of love. The principle of compassion is basically to accept them as they are, and strive so that they can live their lives naturally, like other normal children. Therefore, efforts that need to be made for them: (a) not to be indulgent, (b) not to be indifferent to their needs, and (c) to provide tasks that are appropriate to the child's abilities.

b. Principles of individual services. Individual services in order to educate children with disabilities need to get a larger portion, because every child has 
disabilities in different types and degrees from one another. Therefore, efforts that need to be made for them during their education: (a) the number of students served by the teacher is no more than 4-6 people in each class (Ikhwan, 2012), (b) curriculum arrangements and lesson schedules can be flexible, (c) classroom arrangement must designed so that the teacher can reach all of his students easily, and (d) modification of learning aids.

c. Principle of readiness. To receive a particular lesson preparedness is needed. Especially the child's readiness to get the lessons to be taught, especially the prerequisite knowledge. For example, mentally retarded children before being taught sewing lessons need to be taught how to insert needles first. Other examples of children with disabilities in general have a tendency to quickly get bored and get tired quickly when receiving lessons. Therefore, teachers in this condition do not need to give new lessons, but they are given fun and relaxed activities, after being refreshed the teacher can continue to provide lessons.

d. Principles of performance. The smooth learning in children with disabilities is strongly supported by the use of teaching aids as a medium. In addition to facilitating teachers in teaching, another function of the use of teaching aids as learning media for children with disabilities is to facilitate students' understanding of the material presented by the teacher. Props that are used for media should be attempted to use the original object or situation, but if it is difficult to do, it can use artificial objects or at least the image. For example, introducing animals to deaf children by means of children told to put pictures on a panel is better than the teacher just telling the story in front of the class. Blind children who are introduced to star fruit, it will be better to bring the original object than the imitation, because besides children can recognize shapes and sizes, also can know the taste.

e. Motivation principle. The principle of motivation is more focused on how to teach and provide evaluations tailored to the conditions of children with disabilities. For example for blind children, learning orientation and mobility emphasized in the introduction of animal sounds would be more interesting 
and impressive if they were invited to the zoo. For mentally retarded children to explain the four healthy five perfect foods, perhaps it would be more interesting if the original material was displayed then given to the child to be eaten rather than just in the form of pictures.

f. The principle of learning and working groups. The direction of emphasis on the principle of learning and working groups as one of the basics of educating children with disabilities so that they as members of the community can get along with the community without having to feel inferior without having to feel inferior to normal people. Therefore, the egocentric or selfish nature of children who are deaf because they do not experience feelings, aggressively, and destructively in children with disabilities needs to be minimized or eliminated through learning and working in groups. Through these activities they are expected to be able to understand how to get along with others properly and naturally.

g. Principle of skill. Skills education given to children with disabilities, in addition to functioning selectively, educatively, recreation and therapy, can also be used as a provision in their future lives. Selective means to direct the interests, talents, skills and feelings of children with disabilities effectively. Educative means guiding children with special needs for logical thinking, feeling refined and the ability to work. Recreation means that the element of activity exhibited is very pleasant for children with disabilities. But it means that the skill activities provided can be one of the means of habilitation due to the abnormality or disability they carry.

h. The principle of planting and improving attitude. Physically and psychologically, the attitude of children with disabilities is not good enough so that they need to be sought so that they have a good attitude and not always be of concern to others. For example blind children who often shake their heads to the left and right, or shake the body that is done unconsciously, or deaf children have a tendency to be suspicious of others due to their inability to capture other people's conversations and others. 


\section{Obstacles For Blind Children}

Basically blind children do not have cognitive impairments, they are just like normal children in general. Because based on the results of the investigation it turns out that blind children have normal intelligence so they do not have cognitive impairments, they only experience obstacles in their development related to their disposition. Things related to eye stimulation are replaced with other senses as compensation (Ahmadi dan Supriyono, 2004). The main obstacle that children with visual impairments carry is the failure of the sense of sight.

Through the sense of sight a person is able to observe the world around not only its shape (on three dimensional objects), its color and dynamics. Through these senses also most information stimuli are received and then forwarded to the brain resulting in certain impressions and perceptions of these stimuli, which in turn can stimulate a person's growth and cognitive development so that they are able to develop optimally (Soemantri).

So with the disruption of a person's sense of sight will affect his ability to interact with the surrounding environment and a little hampered in capturing information stimuli that should be received by the sense of sight.

As with cases that occur in blind children, with a loss of part or all of the visual function in blind children will have a negative impact on other abilities, the ability to utilize other physical abilities, such as the development of psychological functions and social adjustment (Effendi, 2006).

Children with partial vision barriers are usually still able to use the remnants of their eyesight even though they have difficulty using their sense of sight especially when they read a reading in normal size. Whereas children who are totally blind are those who recognize people, objects, or their environment by using tactile abilities or palpation, with a sense of hearing, and with their sense of smell (Delphi, 2009).

Basically, children with impaired vision function either partially or completely can have an influence on their development such as: cognitive development, academic development, development of orientation and mobility and social and emotional development. 
This results in blind children in carrying out their roles as social beings in their environment often experiencing obstacles. This is because blind children are less able to have the normative requirements demanded from their environment, for example: the ability to adjust to socialization, how to interact with people around them, how to express gratitude, mutual respect, ability to express, how to wave, and others-other. Therefore blind children need education, direction, training and broad educational opportunities and skills for blind children so that these problems do not spread so that they can disrupt the development of blind children.

\section{Pattern of Guidance for Children with Special Needs (Blind)}

The word "pattern" is defined as a model, example, guideline (design), work basis (Darmawan, dkk, 2010). While the word "coaching" is defined as effort, action, and activities carried out in an efficient and effective way to obtain better results (Departemen Pendidikan dan Kebudayaan, 1990). The term coaching refers to an activity of maintaining and perfecting an existing one (Soetopo dan Soemanto, 1986). Definition of coaching according to psychology, coaching can be interpreted as an effort to maintain and bring about a situation that should occur or maintain the situation as it should.

So the pattern of coaching can be interpreted as a business plan (Wahyudi, 2018), actions carried out in an efficient and effective way to obtain better results in accordance with expectations and goals.

\section{Coaching Aspects}

Guidance for children can be started at an early age, even in the womb, a child must get an education. As in Islam, the child's religious seeding starts from being in the womb of the mother, then after the child is born and their physical development is very fast, it must be accompanied by the development of the faith, morality, and intelligence of the child through the family (Susanti, 2016).

So that's when the elements of child development must be planted immediately through the basis of Islamic education (Ikhwan, 2014). Islamic 
education aims to build the character of strong students facing various trials in life and painstaking, patient and intelligent in solving problems faced.( Beni Ahmad Saebani dan Hendra Akhdiyat, 2009) In this case Zuhairini also put forward the aim of Islamic education, which included the following matters:

a. Development of personality (formal value), namely attitudes, rational practical thinking, objectivity, loyalty to the nation and ideology, aware of moral and religious values (Anisah, 2018) (Ikhwan, 2013) (Ikhwan \& Fauzi, 2018).

b. Fostering aspects of knowledge (material values), namely science material itself.

c. Fostering aspects of skills, practical skills.

d. Healthy physical and spiritual formation (Saebani dan Akhdiyat, 2009).

Islam as a religion is also very concerned about education. The instructions of the scriptures and the sunnah of the prophet clearly encourage the followers of Islam to increase the skills and morality of the young generation with high nobility and skill (Febriansyah, Daroini, \& Widowat, 2019).

Related to the development of blind children is influenced by the level of type of disability. Because of that in the effort to overcome this type of disability are ways of guidance and special coaching so that they are able to socialize in the community that is socializing, working exercises, and working according to the abilities and results of the training achieved For example, training in the field of massage skills. Development and development of social science, as informance. Development and development in the field of art and music (Ahmadi dan Supriyono, 2004).

\section{Educational Foundation for Children with Special Needs}

The mandate of the right to education for persons with disabilities or disability is stipulated in Law No. 20 of 2003 concerning Article 32 of the National Education System stated that: "Special education (special education) is education for students who have difficulty in following the learning process due to 
abnormalities physical, emotional, mental, social " (Sidiq, 2017). Provisions in Law No. 20 of 2003 for children with disabilities is very significant because it provides a strong foundation that children with disabilities need to get the same opportunities as those given to other normal children in terms of education and teaching (Effendi, 2006).

In addition there are three foundations that underlie the need for education for children with disabilities, as follows:

a. Religious foundation

Every religious person of any religion who is adhered to, is obliged to help one another and do good for his fellow human beings. The obligation to help and do good to fellow human beings includes things that are material and spiritual in nature (Sapariadi, 1982).

Children with special needs are those who need help, because of their limitations so that they need help from others. Likewise with children with special needs they remain in the same condition if they do not get education and also coaching. So as religious people, they should be able to provide assistance, because they also have the right to get education so that they can fulfill their obligations to God, society, and to themselves.

b. Juridical Platform

1) The basis of Indonesian national education is the state philosophy of Pancasila and the 1945 Constitution, namely:

Article 27 paragraph (1) of the 1945 Constitution reads: "All citizens are at the same time in law and government and are obliged to uphold the law and government with no exceptions. Then article 31 paragraph (1) reads, "Every citizen has the right to receive teaching".

2) Basic Education Law No. 12 of 1954, namely: Article 6 paragraph (2): Extraordinary education and teaching are given specifically for those in need.

3) Law No. 2 of 1989 concerning the National Education System (UUSPN) and the Broad Guidelines of the State Policy (GBHN) emphasizes that children with disabilities have the right to education services. In UUSPN it is stated 
that they have the right to obtain extraordinary education (Utami Munandar, 1998).

c. Paedagogical Platform (Sapariadi, 1982)

It has been formulated that education is essentially a conscious effort to develop the personality and abilities of students inside and outside school that last a lifetime. Obviously through this formula that education is essentially needed by anyone, anytime, anywhere.

In this case because of obstacles, disruptions and so on educatively, children with disabilities need special education services, because public schools cannot provide effective education.

From the didactic perspective, it is assumed that in children with disabilities there is potential and ability that is still possible to develop, because in essence there is no potential for zero in humans. Only because of their abnormalities they need educational services specifically to develop their personal potential.

It appears here that educational factors play an important role in children with disabilities in addition to the potential and talent they have.

\section{METHODS}

This study uses the interpretive paradigm through a qualitative approach, the type of case study. The location of this study according to the author is very unique from other locations because the Aisyiah Ponorogo Orphanage as a nonformal educational institution that carries out its duties and functions in learning and fostering children, including dealing specifically with children who have visual impairments. The technique of collecting data uses interviews, observation and documentation. The analytical tool used is the qualitative analysis model of Miles and Huberman data reduction, data display and verification. Check the validity of data using triangulation; credibility, transferbility, depandibility and confirmability. The focus of this study is to describe the foundation of guidance carried out on children with special needs (blind) and to describe aspects of coaching for children with special needs (blind). 


\section{FINDINGS}

\section{Foundation of Guidance for Children with Special Needs (Blind)}

That the school does not accommodate all children regardless of physical, intellectual, social, emotional or other conditions. Because every child has the right to a proper education. As an extraordinary school that is a school that accommodates children who have special needs. So that the learning is tailored to the needs of children rather than children which are adjusted to the speed and nature of the learning process.

Aisyiah Ponorogo Orphanage is a place where children who have special needs or children who are less able to get education and guidance. Because based on the 1945 Constitution paragraph 31 that every citizen has the right to education and decent livelihood. Then in this institution besides helping disadvantaged children also a container for learning especially for children who have special needs. As stated by Ustadz Hadianto as the deputy head of the orphanage stating that:

Apart from our vision and mission, there are two things that underlie education for blind children, namely

a. Reason for religion: that is based on the Koranic letter ayat Period verse 1-4 and Ali Imron verse 104.

b. Social reasons: that in the community blind children are considered rubbish.

Therefore we strive to provide guidance and develop the talents of blind children so that they can be well received in society.

Based on the above opinion, it has inspired the orphanage to provide the best service because it is in accordance with its vision of wanting to make a pilot home that is based on moral, scientific, and independent individuals (Dalmeri, 2018).

This is also confirmed by the profile of the institution which has the founding foundation, as follows:

a. The Qur'an of Ali Imron verse 104 and the letter 'Abasa verses 1-4. 
b. Helping government programs participate in the intellectual life of the nation, especially the realization of the 1945 Constitution Chapter XIII article 31 paragraph 1.

c. The basis of humanity, with the idea that blind children are also creatures of God who are entitled to proper education, besides having advantages that normal children do not have.

\section{Coaching Aspects}

The formation of each child is different according to their needs, as well as children who have special needs. In this orphanage they are nurtured and developed their talents in accordance with the talents of each student.

Foster children are trained to be independent so that when they leave the institution they no longer ask for help from others. In addition, students are equipped with knowledge of both science and technology. This is evidenced by the existence of computer and internet space where children can learn computers so that they do not miss or stutter technology. And they can express their talents in the computer field. children who are talented in the music field. For the religious sector there is also the art of Qira'atil Qur'an and muhadharah. Aside from that as a spiritual formation, the orphanage held regular recitations at the beginning of the month, besides that foster children could also attend the Al Manar morning recitation and also be able to attend an invitation to recitation from another orphanage.

Development of children is not only spiritual but also physical, this is also applied in the Aisyiah Ponorogo Orphanage by holding sports for foster children (Ikhwan, 2017).

Not only normal children have talent, but blind children are also not inferior, this is evidenced by the achievement of blind children in the field of music that they have appeared everywhere. So this can be a provision for children when they have left the orphanage that they have extraordinary talent. In addition to music, there are also many blind children who are interested in the field of computers, besides that there are also massage skills training that they can later 
develop when they are already involved in the community. is to establish BLK (vocational training center). In addition, blind children can also continue their studies to a higher level, including many who become educators (Arista, 2019).

In the aspect of children's knowledge development, in this institution children get education including TPA activities, religious studies, and tutoring. But in learning there must be differences in blind children with normal children even though in terms of cognitive blind children there is no interference. As caregivers must be able to understand children, especially the character of different children. Therefore, there is an entrance test at the Aisyiah Ponorogo Orphanage.

The character of different children makes the handling of each child different, especially for blind children they have characters who are easily offended and suspicious of others. Besides that, in learning there are also obstacles faced, as also expressed by cleric Hadianto as caregivers and representatives of the Aisyiah Orphanage in learning that children experience difficulties in understanding, so caregivers must slowly provide material, so that children who are blind can be accepted.

Learning material delivered to blind children in teaching is not enough with the classical method. This is due to the level of disability and different levels of ability, so the instructor must pay attention to the child one by one or also called individual teaching (Hadianto, 2019).

In addition there were also other obstacles as expressed by Ustadz Elferin Dyah Arista, namely:

In addition to the way their understanding tends to be slow because of their disposition but also because the class condition is different levels of students make children difficult in material because their classes are still mixed for 3 classes while for the other three classes the class is in accordance with their level. Apart from that which is our problem, which is about classrooms that are still inadequate so we have to move around in determining the class, which can be in the hall, the terrace of the mosque, and so on.

So from the description above, the researcher can conclude that the form of foster care in the Aisyiah Ponorogo Orphanage is that in addition to classroom 
learning, there are other coaching, which can be moral formation, unity and also fostering children's interests and talents that can be poured with music, Qiraatil Qur'an, as well as computers and massage skills.

From the results of observations made by the researchers it was found that the training applied at the Aisyiah Ponorogo Orphanage was already underway, both in the formation of knowledge, independence, personality and also their skills. Only in the field researchers saw, the education for afternoon classes was still constrained by space class, so learning is done outdoors namely on the terrace of the mosque.

Based on the results of interviews with several foster children of the Aisyiah Ponorogo Orphanage that what they get at the Aisyiah Orphanage is that in addition to general knowledge they can also develop their talents and interests. Among them can be music and also the art of reading the Qur'an or Qira' keep the Qur'an. 


\section{RESULTS AND DISCUSSION}

\section{Analysis of the Foundation of Guidance for Children with Special Needs}

(Blind)

Children with special needs are children who have special characteristics that are different from children in general without always showing mental, emotional or physical disabilities. One of them which includes children with special needs is blind children. Blind children are children who experience interference with their sense of vision so they have to use other senses as a substitute for the sense of touch. However, blind children are not only those who are blind but who experience partial or half-sighted blindness or also called low vision.

Basically, children with impaired visual function, either partially or completely, can have an influence on their development, such as: cognitive development, academic development, development of orientation and mobility and social and emotional development. For this reason, blind children also need special education.

As in Law No. 20 of 2003 concerning Article 32 of the National Education System, it is stated that: "Special education (extraordinary education) is education for students who have a level of difficulty in following the learning process due to physical, emotional, mental, social abnormalities". The provisions in Law No. 20 of 2003 also provide opportunities for blind children to get education and teaching.

In addition there is also a foundation that underlies the education of children who have special needs, including blind children. Among them are religious foundations, juridical grounds and pedagogical grounds.

In the religious foundation that every religious person of any religion adhered to, it is obligatory to help one another and do good to fellow human beings that is in the form of material and spiritual things. Likewise with blind children, they also need help that is able in the form of education and coaching assistance specifically for them. 
Whereas based on the juridical basis described in the law, namely in article 27 paragraph (1) of the 1945 Constitution it reads: All citizens are at the same time in law and government and are obliged to uphold the law and government with no exceptions. Then article 31 paragraph (1) reads, "Every citizen has the right to receive teaching". Besides that in the main education law no. 12 of 1954, namely in article 6 paragraph (2): "Extraordinary education and teaching are given specifically for those in need". And the last is in Law number 2 of 1989 concerning the National Education System (UUSPN) and the General Guidelines of State Policy (GBHN) emphasizing that children with disabilities have the right to receive education services. In UUSPN it is stated that they have the right to obtain extraordinary education.

From the didactic point of view, it is assumed that children with disabilities have potential and abilities that are still possible to develop, because in essence there is no zero potential in humans. Only because of their abnormalities they need educational services specifically to develop their personal potential. Children with visual impairments have the potential to develop well, because they also have normal intelligence. So that with special education services they can develop well and be able to socialize with the community.

At the Aisyiah Ponorogo Orphanage children with visual impairments are assisted by education and coaching which can be useful for blind children. Because basically as religious people, it should always help each other with people in need and as a form of caring and as a form of worship to Allah SWT, the caregivers have devoted themselves to helping and helping others, especially to children who have special needs namely blind people.

Basically every child has the potential, so do blind children who also have extraordinary potential. Then with the right education services their potential can develop optimally.

\section{Analysis of aspects of Child Development at Aisyiyah Orphanage}

Guidance for children can not be separated from what is needed by children as well as for children who have special needs. The age of the child also affects 
their handling especially for teenagers they are also like normal children who have their own world.

Blind children need education like normal children, but the coaching is different because it is related to their abilities. Blind children tend to be easily offended and suspicious of others so they need personality-related development. In addition, knowledge and skills which with knowledge and skills will be very useful for children.

In Islamic education it aims to build strong child characteristics through the coaching that has been done (Ikhwan, 2018). The goals of Islamic education according to Zuhairini are as follows:

a. Fostering personality (formal value), namely attitude, rational practical thinking, objectivity, loyalty to the nation and ideology, aware of moral and religious values.

b. Fostering aspects of knowledge (material values), namely science material itself.

c. Fostering aspects of skills, practical skills.

d. Healthy physical and spiritual formation.

Related to the aspects of coaching above, the Aisyiah Ponorogo Orphanage has also applied from these aspects of coaching. Among them is the development of personality through order that must be adhered to by all santri, but if violated will be given a reprimand or sanction in which the sanctions are educational. So with this order can make good habits and will form a personality that has the character of kharimah.

Science is also the subject of education, so science must be given, both general knowledge and religion. Then in this orphanage there are activities to increase the knowledge and insight of blind children, even though they have been given at morning school, namely at the SLB. The activities include through afternoon school, TPA, tutoring lessons, religious studies.

In addition, the development of skills and skills must also be considered because the development of this potential will be useful for children, especially when they have been involved in the community, namely they already have the 
skills and are able to socialize well in the community. As for skill development through muhadharah activities, organizations, in addition to skills development through learning the reading arts of the Qur'an, music, computers and also massage/massage skills. In addition to developing children's talents in the Aisyiah Ponorogo Orphanage through the provision of BLK (Work Training Center) for those with visual impairments and non-visual impairments.

Children's health must also be considered because to support the development process so that the goal is achieved. So as physical formation, orphanages always hold joint sports or walk around the orphanage complex while also maintaining cleanliness, namely the cleanliness of the room will be the responsibility of the child and this also trains their independence. A healthy body is not enough and must be accompanied by a healthy spirit, so to provide spiritual guidance for children, that is through spiritual showering by holding regular recitations, such as in an orphanage that conducts regular recitation at the beginning of each month. In addition, children are also accustomed to praying in congregation and dhikr.

There is no obstacle for children to get education as long as there is intention and effort, as well as blind children they can continue their education to a higher level. This is evidenced by the presence of blind people who can study and become educators. In addition, those who have musical talents and the Tilawatil Qur'an which normal people cannot do.

\section{CONCLUSION}

The foundation of fostering children with special needs (blind) is Law No. 20 of 2003 concerning Article 32 of the National Education System and in the Qur'anic letters of the Abas verses 1-4. Aspects of guidance carried out on children with special needs (visual impairments) carried out at the Aisyiah Ponorogo Orphanage are personality development through order that will become a habit so as to form a personality that has the character of kharimah. Development of knowledge through afternoon school, TPA, lesson tutoring, as well as religious studies, skills development through muhadharah activities, 
organization, skills development through Al-Qur'an reading, computer, and massage arts, spiritual development through early routine recitation month, and the last is physical formation through regular exercise. 


\section{REFERENCES}

Ahmadi, Abu dan Widodo Supriyono. 2004. Psikologi Belajar Edisi Revisi. Jakarta: PT. Rineka Cipta.

Anisah, Z. 2018. Realitas Kehidupan Islami dalam Novel Surat Kecil untuk Tuhan Karya Agnes Davonar (Kajian Mimetik). Istawa: Jurnal Pendidikan Islam, 3(1), 1-26. doi:http://dx.doi.org/10.24269/ijpi.v3i1.1000.

Dalmeri, S. 2018. Concentration on Learning Program Development in Islamic Education. Al-Hayat: Journal of Islamic Education, 2(2), 57-74.

Delphi, Bandhi. 2009. Pembelajaran Anak Berkebutuhan Khusus dalam Setting Pendidikan Ink/usi.Yogyakarta: PT Intan Sejati Klaten.

Depdiknas. 2003. Undang-undang RI tentang Sistem Pendidikan Nasional No 20 Tahun 2003. Bandung: Citra Umbara.

Effendi, Mohammad. 2006. Pengantar Psikopedagogik Anak Berkelainan. Jakarta: PT. Bumi Aksara.

Ferry Irawan Febriansyah, Daroini, A., \& Widowat, W. 2019. The Role of Islamic Education In Student Organizations to Realize Human Resources In The Review of Higher Education Law Perspectives. Al-Hayat: Journal of Islamic Education, 3(1), 61-67. https://doi.org/https://doi.org/10.35723/ajie.v3i1.51.

Ikhwan, A. 2012. The Meanings of Teachers Professions in Islamic Educational Management. In IACiem (International Annual Conference on Islamic Educational Management). Malang: IIUM Malaysia \& Postgraduate UIN Malang Indonesia. Retrieved from https://scholar.google.co.id/citations?user=67k8WHYAAAAJ\&hl=id\&oi=ao $\# \mathrm{~d}=\mathrm{gs} \_$md_cita$\mathrm{d} \& \mathrm{p}=\& \mathrm{u}=\% 2 \mathrm{Fcitations} \% 3$ Fview_op\%3Dview_citation\%26hl\%3Did\%26us er\%3D67k8WHYAAAAJ\%26cstart\%3D20\%26pagesize\%3D80\%26citation_ for_view\%3D67k8WHYAAAAJ\%3A5nxA0vEk-isC\%26tzom\%3D-420.

---------, 2013. Pengembangan Kurikulum Pendidikan Agama Islam (PAI). Malang: Insan Cita Press dan STAIM Tulungagung.

---------, 2014. Integrasi Pendidikan Islami (Nilai-Nilai Islami dalam Pembelajaran). Ta'allum: Jurnal Pendidikan Islam, 2(2), 184. https://doi.org/10.21274/taalum.2014.2.2.179-194. 
2017. Development Of Quality Management Islamic Education In Islamic Boarding School (Case Study Madrasah Aliyah Ash Sholihin). A/Hayat: Journal of Islamic Education, 1(1), 117. Retrieved from http://alhayat.or.id/index.php/alhayat/article/view/7.

2018. Filsafat Pendidikan Islam: Memahami Prinsip Dasar. Yogyakarta: Diandra Kreatif. $\quad$ Retrieved from https://scholar.google.co.id/citations?user=67k8WHYAAAAJ\&hl=id\&oi=ao \#d=gs_md_cita$\mathrm{d} \& \mathrm{p}=\& \mathrm{u}=\% 2$ Fcitations\%3Fview_op\%3Dview_citation\%26hl\%3Did\%26us er\%3D67k8WHYAAAAJ\%26citation_for_view\%3D67k8WHYAAAAJ\%3AIW HjjKOFINEC\%26tzom\%3D-420.

Ikhwan, A., \& Fauzi, F. T. 2018. Islam and Civilization: Islam as Source of Value for Human Life. In R. Rohim, A. S. Ahmar, R. Hidayat, \& J. Simarmata (Eds.), WESTECH 2018 (p. 11). Medan: EAI: Research Meets Innovation. https://doi.org/10.4108/eai.8-12-2018.2283958.

Munandar, Utami.1998. Pengembangan Kreatifitas Anak Berbakat. Jakarta: PT. Rineka Cipta.

Pengertian Pembinaan. http://www.masbied.com/2012/04/09/pengertianpembinaan-menurut-psikologi/, diunggah pada 9 april 2012.

Saebani, Beni Ahmad dan Hendra Akhdiyat. 2009. IImu Pendidikan Islam 1. Bandung: Pustaka Setia.

Sapariadi, et.al. 1982. Mengapa Anak Berkelainan Perlu Mendapat Pendidikan. Jakarta: Balai Pustaka.

Sidiq, U. 2017. Organizational Learning at Islamic Boarding School In Entering Global Era. A/-Hayat: Journal of Islamic Education, 01(01), 1/19. Retrieved from http://alhayat.or.id/index.php/alhayat/article/view/6.

Soemantri, tt. Undang-Undang Dasar 45. Surakarta: Putra Mandiri.

Susanti, S. 2016. Membangun Peradaban Bangsa Dengan Pendidikan Karakter. Istawa: Jurnal Pendidikan Islam, 1(2), 138 -159. doi:http://dx.doi.org/10.24269/ijpi.v1i2.173

Sutjihati. 2006. Psikologi Anak Luar Biasa. Bandung: Refika Aditama.

Wahyudi, A. 2018. Character Education Development Pattern: Efforts to Empower School Managers. Al-Hayat: Journal of Islamic Education, 3(2), 262-270. https://doi.org/https://doi.org/10.35723/ajie.v2i2.41. 